\title{
Unemployment and child abuse
}

\author{
L S TAITZ, J M KING, J NICHOLSON, M KESSEL
}

\begin{abstract}
The employment state of men living in the homes of children at the time that child abuse was diagnosed was determined. The series included a wide range of abuse, including non-accidental injury, failure to thrive, neglect, and emotional deprivation. Two cohorts of children seen during $1974-9$ and $1980-5$ were compared; these periods were chosen because a large increase in unemployment began in Sheffield in 1980. Although the proportion of the men without work was significantly increased during the second period, this increase could not be ascribed to the rise in either long term or short term unemployment among those who had previously been in regular employment. It was accounted for by a rise in the proportions of single parent families and families in which the resident man had never had regular employment. This may reflect an increase in pregnancies among young mothers.
\end{abstract}

There was no evidence to support the belief that the loss of a job in otherwise stable families leads to an increase in child abuse.

\section{Introduction}

Attention has recently been drawn in an authoritative series of papers to the possible medical consequences of unemployment. ${ }^{1}$

TABLE I-Numbers of cases of child abuse and non-accidental injury 1974-85

\begin{tabular}{lrrrrrrrrrrrr}
\hline & 1974 & 5 & 6 & 7 & 8 & 9 & 80 & 1 & 2 & 3 & 4 & 5 \\
\hline No of cases of abuse & 16 & 9 & 18 & 22 & 16 & 16 & 21 & 22 & 16 & 14 & 13 & 26 \\
No of cases of non-accidental injury & 8 & 6 & 5 & 12 & 7 & 8 & 11 & 16 & 9 & 8 & 7 & 18
\end{tabular}

One possible consequence is an increased risk of abuse of children whose father has lost his job. The city of Sheffield has seen a dramatic increase in unemployment since 1980 with the collapse of steelmaking and decline in heavy industry. If unemployment is an important factor in child abuse, particularly non-accidental injury, a comparison of child abuse before and during a period of high unemployment might be expected to show an increase in abuse during the period of high unemployment and a proportionate rise in the number of out of work fathers among the families. To test this hypothesis we examined the work state of men living in families with an abused child seen at this hospital from 1974 to 1985 .

\section{Subjects and methods}

This series comprised all cases of child abuse that were referred to one paediatrician (LST) at this hospital and was a representative sample of all cases in Sheffield, accounting for $25-40 \%$ of cases in the overt category on the child register. Altogether 209 children seen at this hospital in two six year periods, 1974-9 and 1980-5, showed unequivocal evidence of the consequences of one of the forms of child abuse. A further 57 children considered to be at risk of abuse and 30 who had been abused but had additional organic disease were not included in the analysis.

Each child was allocated a primary diagnosis: non-accidental injury in 115 , failure to thrive in 38 , sexual abuse in five, and deprivation syndrome in 51. Although many children suffered multiple forms of abuse, for the purpose of this study they were listed only once. Thus a child with both nonaccidental injury and failure to thrive was listed as having non-accidental injury. Children listed as having deprivation syndromes were those without non-accidental injury or failure to thrive who had development delay ascribable to deprivation. The time periods $1974-9$ and $1980-5$ were chosen because the first large rise in unemployment was noted in the year ending March 1981 (from 6.2\% in the preceding year to $12 \cdot 1 \%$ ).

Altogether 97 children were referred during $1974-9$ and 112 during 1980-5. The family of each child was classified into one of five categories. (1) Single parent family: no man was regularly resident at the time the abuse was

TABLE I-Employment state of resident man at time of abuse. Figures are numbers (percentages) of men

\begin{tabular}{|c|c|c|c|c|c|c|c|c|}
\hline & \multirow[b]{2}{*}{$\begin{array}{c}\text { No of } \\
\text { families }\end{array}$} & \multirow[b]{2}{*}{$\begin{array}{l}\text { Single } \\
\text { parent } \\
\text { family }\end{array}$} & \multicolumn{6}{|c|}{ Employment state of resident man } \\
\hline & & & In work & $\begin{array}{l}\text { Never } \\
\text { worked }\end{array}$ & $\begin{array}{l}\text { Long term } \\
\text { unemployed }\end{array}$ & $\begin{array}{l}\text { Short term } \\
\text { unemployed }\end{array}$ & Uncertain & $\begin{array}{l}\text { Single parent families plus } \\
\text { those in which man had } \\
\text { never worked }\end{array}$ \\
\hline $\begin{array}{l}1974-9 \\
1980-5 \\
\chi^{2} \\
\text { p Value }\end{array}$ & $\begin{array}{r}97 \\
112\end{array}$ & $\begin{array}{c}21(22) \\
38(34) \\
3 \cdot 28 \\
\text { NS }\end{array}$ & $\begin{array}{l}48(49) \\
29(26) \\
11.4 \\
0.001\end{array}$ & $\begin{array}{c}17(18) \\
33(29) \\
4.07 \\
0.05\end{array}$ & $\begin{array}{c}\text { cases of abuse } \\
6(6) \\
9(8) \\
0 \cdot 12 \\
\text { NS }\end{array}$ & $\begin{array}{l}0 \\
1(1) \\
0.0 \\
\text { NS }\end{array}$ & $\begin{array}{l}5(5) \\
2(2) .\end{array}$ & $\begin{array}{l}38(39) \\
71(63) \\
11 \cdot 3 \\
0.001\end{array}$ \\
\hline $\begin{array}{l}1974-9 \\
1980-5 \\
\chi^{2} \\
\text { p Value }\end{array}$ & $\begin{array}{l}46 \\
69\end{array}$ & $\begin{array}{c}9(20) \\
18(26) \\
0.65 \\
\text { NS }\end{array}$ & $\begin{array}{l}26(57) \\
18(26) \\
9.57 \\
0.001\end{array}$ & $\begin{array}{c}\text { Nor } \\
9(20) \\
24(35) \\
2 \cdot 42 \\
\text { NS }\end{array}$ & $\begin{array}{l}\text {-accidental injur } \\
\begin{array}{c}2(4) \\
4(6) \\
0.0 \\
\text { NS }\end{array}\end{array}$ & $\begin{array}{l}0 \\
1(1) \\
0 \cdot 0 \\
\text { NS }\end{array}$ & $\begin{array}{l}0 \\
4(6)\end{array}$ & $\begin{array}{c}18(39) \\
42(61) \\
4.39 \\
0.04\end{array}$ \\
\hline
\end{tabular}

NS $=$ Not significant.

University Department of Paediatrics, Children's Hospital, Sheffield S10 2TH

L S TAITZ, MD, FRCP, senior lecturer

J M KING, MB, MRCP, lecturer

J NICHOLSON, MB, MRCP, lecturer

M KESSEL, BA, AMIMSW, senior social worker

Correspondence to: Dr Taitz. diagnosed. (2) In work: the resident man had regular work at the time the abuse was diagnosed. (3) Never worked where the resident man had never had regular employment (for more than six months). (4) Long term unemployment: the resident man had previously been in regular work (for more than six months) but had not worked in the past two years or longer. (5) Short term unemployment: the resident man had been in regular work (for more than six months) but had been unemployed for the past two years or less.

Statistical analysis was by $\chi^{2}$ test with Yates's correction. 


\section{Results}

Table I shows the number of cases of child abuse referred to this hospital ineach year of the study; there was no definite trend. Table II compares the proportions of families in each category of employment during the two time periods. There was a highly significant fall in the proportion of resident men who were working, both for all cases of abuse and for cases of non-accidental injury alone, between the two time periods $(p<0.001)$. There was no significant increase in long term unemployment, short term unemployment, or long term and short term unemployment combined between the two cohorts. The increase in the proportion of single parent families did not reach significance for either the cases of non-accidental injury or the whole series. There was a significant rise in the proportion of men in the whole series who had never worked. When single parent families and families in which the resident man had never worked were combined the increase between the two periods was significant for both non-accidental injury and all cases of abuse.

The proportions of families in the two time periods in which the resident man was unemployed were related to the unemployment among Sheffield men in the median years of the two time periods, 1977 and 1983 (table III). There was no significant increase in long term or short term unemployment between the periods in the families with an abused child despite a 3.5-fold increase in the population as a whole. Table IV shows the percentage increase in unemployment between the two periods compared with that in Sheffield as a whole.

TABLE III-Proportions of resident men in skort term and long term unemployment in each time period compared with overall wnemployment rates. Figures are percentages

\begin{tabular}{|c|c|c|c|c|}
\hline & $\begin{array}{l}\text { Long term } \\
\text { unemployed }\end{array}$ & $\begin{array}{c}\text { Short term } \\
\text { unemployed }\end{array}$ & $\begin{array}{l}\text { Long term and } \\
\text { short term } \\
\text { combined }\end{array}$ & $\begin{array}{l}\text { Male unemployment in } \\
\text { Sheffield (and year) }\end{array}$ \\
\hline \multicolumn{5}{|c|}{ All cases of abuse } \\
\hline $1974-9$ & $7 \cdot 9$ & 0 & $7 \cdot 9$ & $5 \cdot 0(1977)$ \\
\hline $1980-5$ & $12 \cdot 2$ & 1.4 & $13 \cdot 6$ & $17 \cdot 8(1983)$ \\
\hline & $0 \cdot 12$ & 0 & 0.55 & \\
\hline \multicolumn{5}{|c|}{ Non-accidental injury } \\
\hline $1974-9$ & $5 \cdot 4$ & 0 & $5 \cdot 4$ & $5.0(1977)$ \\
\hline $1980-5$ & $7 \cdot 8$ & 1.9 & $9 \cdot 7$ & $17 \cdot 8(1983)$ \\
\hline$x^{2}$ & 0 & 0 & 0.44 & \\
\hline
\end{tabular}

None of the changes approached significance.

TABLE IV-Percentage increase in unemployment (1974-9 v 1980-5)

\begin{tabular}{lccc}
\hline & $\begin{array}{c}\text { Those in short term and } \\
\text { long term unemployment }\end{array}$ & $\begin{array}{c}\text { Those never } \\
\text { in work }\end{array}$ & $\begin{array}{c}\text { All out of } \\
\text { work }\end{array}$ \\
\hline Total population & 67.9 & $94 \cdot 8$ & 256.0 \\
All cases of child abuse & 79.6 & 105.9 & 96.8 \\
Cases of non-accidental injury & & 91.6 \\
\hline
\end{tabular}

\section{Discussion}

Unemployment among men in Sheffield has increased dramatically since 1980; before that year the figure was fairly stable. Thus the figures for the median years in the two study periods reported here, $5.0 \%(1977)$ and $17 \cdot 8 \%$ (1983), indicate an increase in male unemployment of $256 \%$. This huge rise was not reflected in the proportions of families with an abused child in which the resident man was unemployed.

Paternal unemployment is often regarded as a risk factor for child abuse. ${ }^{2}$ A recent study described a prevalence of $30 \%$ among children with non-accidental injury in a city with an overall male unemployment rate of $9 \cdot 6 \% .{ }^{3} \mathrm{~A}$ recent review ${ }^{4}$ rightly urged caution in claiming a causal relation betwen unemployment and child abuse simply on the basis of reports that a higher proportion of men resident in families of abused children are out of work. ${ }^{5-8}$ Our data do not support previous views that losing a job increases the risk of violence to children. ${ }^{910}$ As our data show, unless a distinction is made between different sorts of unemployment misleading conclusions may be drawn from raw data, particularly when single parent families with transient cohabitees who may or may not be the father of the child are included. Hence in this study we considered the unemployment state, classified as one of the categories described, of the man resident in the household at the time of the abuse. Households in which there was no resident man were described as single parent families and did not figure in the unemployment data. It became clear that recent or long term unemployment, as defined in this study, in a previously stable family in which there were no other major social problems did not seem to be a risk factor for child abuse. The paucity of such families in our series suggests that in these circumstances the presence at home of a resident man may actually protect against abuse of children. A high proportion of the men who had never had regular work may have been recent school leavers or disturbed men who had never been able to maintain a reasonable level of employment. It is important to note that as the proportions of the various categories of family state were interdependent the $\chi^{2}$ tests comparing them were not independent. Thus any change in the contribution of any one category may have been due to increases or decreases in another category.

Child abuse seems to fall into two broad categories: that in which the abuse is due to social disadvantage and that in which it is a symptom of wider family disturbance, when social disadvantage including unemployment may also be a result of this disturbance. Earlier studies have been divided between those that describe child abuse as occurring in all social circumstances and probably unrelated to social state and those that point to the clear preponderance of abuse in lower social classes. ${ }^{112}$ The third possibility-that much abuse occurs in an unclassifiable element of society, outside usual social class stratification-is clearly important. It is difficult to be sure how such families have been classified in previous studies. It is thus essential in attempting to establish a causal relation between child abuse and unemployment to distinguish between those families in which loss of a job was preceded by stable employment and those in which the resident man had never had regular work.

Given the huge increase in unemployment among a previously stable workforce in Sheffield, we expected this to be reflected in the data on child abuse. There was additionally no substantial evidence of an increase in serious child abuse in Sheffield during the past five years. Our investigations (LST, unpublished findings) showed that one death that might have been due to child abuse was investigated by the coroner (S Variend, personal communication); the father was in regular work. Sudden infant death (cot death) did not increase, nor was there an appreciable upsurge of serious injury or failure to thrive. The proportions of men in short term and long term unemployment over the two study periods did not increase significantly and were well within the figures predicted from the overall rise in unemployment. The number of cases reported and investigated after a much publicised case in which a girl (Jasmine Beckford) died of abuse has increased, but this may reflect a greater sensitivity and caution rather than any spectacular rise in serious injury or death. The proportionate increase in unclassifiable families reported in this study (single parent families and those in which the resident men had never been in regular work) may therefore represent the effect of changing social patterns rather than an epidemic of abuse in this group. Such families account for a high proportion of child abuse, for the mixture of immaturity, frequent pregnancies, poor education, drunkenness, bad housing, and criminality is not conducive to effective child rearing (LST, unpublished findings). Child abuse tends to occur in families in which pregnancies are unplanned, the mothers are often young and unsupported, or the couples are young and immature. This section of the population is growing, which may, therefore, eventually lead to an increase in child abuse.

From the data presented here there is no evidence that the recent increase in unemployment, mainly through sudden redundancy, has had any appreciable effect on the numbers of children being abused. As this study is hospital based and therefore likely to be weighted towards the more severe cases of child abuse it is possible, but unlikely, that a more widely collected sample would produce a different result.

We thank the CHRIS Fund for its generous support of this study. 
References

1 Smith R. "We get on each other's nerves:" unemployment and the family. Br Med $\mathrm{J}$ 1985;291:1707-10.

2 National Society for the Prevention of Cruelty to Children. Information briefing: an overview of the research on the effects of unemployment on the family with particular reference to child abuse. London: National Society for the Prevention of Cruelty to Children, 1985.

3 Cater JI, Easton PM. Separation and other stress in child abuse. Lancet 1980;i:972-4.

4 Madge N. Unemployment and its effect on children. Joumal of Child Psychology and Psychiaty 1983;24:311-9.

5 Young L. Wednesday's children: a study of child neglect and abuse. New York: McGraw-Hill, 1964. 6 Galdston R. Observations on children who have been physically abused and their parents. Am J Psychiatry 1965;122:440-3.
7 Gil DG. Physical abuse of children: findings and implications of a nationwide study. Pediatrics 1969;44:857-64.

8 Creighton SJ. Child victims of physical abuse 1976: third report on the findings of NSPCC special units registers. London: National Society for the Prevention of Cruelty to Children, 1980.

9 O'Brien TE. Violence in divorce prone families. Jourmal of Marriage and the Family 1971;33. 292-8.

10 Steinmetz SK, Straus MA. Violence in the family. New York: Dodd and Mead, 1974.

11 Lynch MA, Roberts J. Consequences of child abuse. London: Academic Press, 1982.

12 Oliver JE. The epidemiology of child abuse. In: Smith SM, ed. The maltreatment of children. Lancaster: MTP Press, 1978.

(Accepted 27 February 1987)

\title{
What are health authorities doing about the health problems caused by unemployment?
}

\author{
CHRISTIANE HARRIS, RICHARD SMITH
}

\begin{abstract}
Unemployment is over three million in Britain, and unemployment is known to be associated with poor health. It has been suggested that health authorities should produce a comprehensive response to the health problems caused by unemployment, and a survey was undertaken to find how many had done so. All the regional and district health authorities in England, the health boards of Wales, Scotland, and Northern Ireland, and the family practitioner committees of England and Wales were asked by letter what they were doing to respond to the health problems of unemployment. A list of suggestions of what they might be doing was enclosed. The overall response rate was $77 \%(255 / 331)$, and $50 \%(127 / 255)$ of the respondents were doing something - $33.3 \%$ (3/9) of the regional health authorities, $64 \%(101 / 158)$ of the district health authorities and health boards, and $26 \%(23 / 88)$ of the family practitioner committees. The paper describes what they were doing. A relation was sought between the level of unemployment in an area and the extent of the response, and a significant association was found.
\end{abstract}

Half of Britain's health authorities are now responding in some way to the health problems associated with unemployment.

\section{Introduction}

More than three million people are unemployed in Britain, and unemployment is strongly associated with poor health. ${ }^{1.5}$ Unemployed middle aged men have a death rate twice that of comparable men in employment. ${ }^{6}{ }^{7}$ Unemployment itself, rather than its common companions such as poverty and poor housing, causes a deterioration in mental health ${ }^{18}$ and is strongly associated with suicide and parasuicide. ${ }^{9}$ Those who are threatened with losing their jobs consult their general practitioners $60 \%$ more often than controls who are in work and are referred $20 \%$ more often for hospital outpatient appointments. ${ }^{10}$

Some have thus argued that health authorities should develop

University College London, London WC1E 6BT

CHRISTIANE HARRIS, BSC, medical student

British Medical Journal, BMA House, London WC1H 9JR

RICHARD SMITH, BSC, MB, assistant editor

Correspondence to: Dr Smith. plans for responding to the health problems of the unemployed, ${ }^{3} 11$ but there is little or no published evidence that any have done so. We have attempted to find out how many health authorities are responding to the health problems of the unemployed and what they are doing. We have also tested the hypothesis that authorities in areas of high unemployment may have done more than those in areas of low unemployment.

\section{Methods and results}

In October 1986 we contacted by letter the regional and district health authorities in England, the health boards of Wales, Scotland, and Northern Ireland, and the family practitioner committees of England and Wales. (Family practitioner committees in the rest of the United Kingdom were not contacted simply because we did not have time.) We asked the authorities to tell us what they were doing about the health problems caused by unemployment and as a prompt enclosed a list of eight measures that migh be taken (table I). If the authorities were doing nothing then we asked them

TABLE I-Steps that might be taken to respond to the health problems of unemployment

(1) Monitoring unemployment and its effects on health in your area

(2) Relaying this information to staff

(3) Taking unemployment into account when allocating resources

(3) Taking unemployment into account when allocating resources
(4) Creating jobs and work-either on your own initiative or together with the Manpower

(4) Encouraging and training staff to familiarise themselves with facilities and benefits for the unemployed, and perhaps seconding some to local community initiatives

(5) Making information about facilities and benefits for the unemployed available to staff. Such facilities include:

advisory bodies

counselling/psychological help

job creation schemes

leisure/recreation schemes

retraining/education

practical skills (such as furniture repair and preparation of cheap but nutritious meals)

women's groups

youth groups

(6) Liaising with local authorities and other health authorities to ensure that efforts are not being duplicated and to assess whether you could do anything to further their efforts (7) Targeting your responses at those most at need

to write "none" on our letter, stamp it with the authority's stamp, and return it in the enclosed stamped addressed envelope. A reminder was sent to all non-respondents after one month.

More than three quarters $(77 \%, 255 / 331)$ of the authorities responded: $64 \cdot 3 \%(9 / 14)$ of the regional health authorities, $72 \cdot 1 \%(158 / 219)$ of the district health authorities and health boards, and $85 \%(83 / 98)$ of the family practitioner committees. Respondents were compared with non-respondents by looking at the proportions with unemployment rates that were high $(15 \%$ 